\title{
Entrepreneurship Learning Model in Improving Student's Spiritual Intelligence
}

\author{
Siti Musrifah \\ Magester Menejemen Pendidikan Islam \\ Universitas Muhammadiyah Sidoarjo \\ Sidoarjo, Indonesia \\ Email:Smusrifah@gmail.com
}

\begin{abstract}
Education means educating people who have knowledge and skills and also in accompanied by faith and right to Allah SWT to be useful people for both individuals and community life. Education can be obtained anywhere and with various models. The model is determined by the things closed to students' life so they can easily receive and practice what they have got from school. This study aims to determine the application of entrepreneurship learning model in improving the spiritual intelligence of students in elementary school. This research uses qualitative descriptive approach to analyze data on the application of enterpreneurship learning model, in improving students' spiritual intelligence. The results of the study showed that learning by enterpreneurship model done by the elementary school students, with the practice of selling or doing the direct entrepreneurship in public. The positive impact in improving students' spiritual intelligence can be seen from habituation in performing honest behavior, politeness in communicating and independent attitude in the learning process to fulfill their needs start from small things. Therefore, it is necessary to follow-up and validate the results of the research by doing data collecting and data documentation toward elementary school students in Enterpreneurship lesson.
\end{abstract}

Keywords-spiritual intelligence; entrepreneurship; learning model

\section{INTRODUCTION}

Enterpreneurship learning model is a very rare activity done at school level because many people assume that entrepreneurship is not one of the educational sections, but an adult activity or profession that is no longer accepted in some companies or is a shift in the busy life of parents who have entered retirement. That assumption is a great chance to decline the country's economy, which every year, unemployment rate of young people who graduated from the education period increased. Judging from the phenomenon that occurs, it requires a joint evaluation of what is an effective step that can hone the intelligence of students in developing the ability and intelligence to teach skills in addressing their own needs, so that the current generation becomes an independent generation and can be responsible for the needs of himself and can develop existing natural resources.

Building entrepreneurial spirit in college is not enough, but the entrepreneurial spirit has to be informed start from elementary school, even in kindergarten level. This will give the intention of the entrepreneurial spirit to become part of their pleasure, not a compulsive, but exciting activity. It seems that they are unaware that in the course of their execution of entrepreneurial learning models, there are so many learning metrics that they can count, communicate well, socialize, independence to the spitual intelligence of how children are polite in the delivery of messages and honesty in entrepreneurship. What makes the problem now is how many schools have applied Entrepreneurship learning model, certainly not many with various problems and probabilities ability and willingness of school. Learning is not only done in the classroom at school, but learning can be done anywhere. The ability of a teacher who became the main role in utilizing and maximizing the time in each condition including when students are practicing entrepreneurship.

Seeing the life history life of Prophet Muhammad SAW, trade or entrepreneurship is the main activity or livelihood, almost all residents of that time had profession as sellers. When the Prophet at that time did selling, it became the time of earning a living and at the same time, he also did boardening the brotherhood (silaturahim) and expanding Islamic Religion. there are so many things that the students can get from the application of the entrepreneur learning model to the level of spirtual intelligence.

From the above background description, I concluded that there are while so many things can be gained in learning entrepreneur model both general science and also science of religion. Thus, the author will try to examine how big in the application of entrepreneurship learning model at elementary school level to improve student's spiritual intelligence. 


\section{RESEARCH METHOD}

This study uses a descriptive qualitative approach with the assumption that qualitative research will obtain a naturalistic find, so as to reveal the problem in detail. The subjects of this study on the entrepreneur's learning model in improving students' spiritual intelligence, while for data collection techniques in this research is by interview, observation, direct observation and decumentation. The data are analyzed through data selecting, data collecting and conclusion withdrawing [1].

\section{LITERATURE REVIEW}

\section{[1] Model}

Models can be interpreted as references that become the basis of particular things [2]. In other words, it also becomes reference that can be followed as an example to assess a particular system. The model is the representation of an object. It is the object or form simplified from the condition of natural phenomena. The model contains information about a phenomenon that was created for the purpose of studying the actual system. The model can be the imitation of a real object, a system or an event that contains only information that is very important di review and discuss [4]. Learning model is a form of learning that is illustrated from the beginning to the end, and then presented typically by the teacher. The learning model according to Bruce Joys and Marsha Weil consists of four groups: a model of social intraction, a model that prefers individual relationships with other peoples' societies and focuses attention on the process where reality is viewed as a social negotiation. This model emphasizes the personal and social relationships among learners that focus on improving the ability to connect with others, engaging in democratic processes and working productively in society.

\section{[2] Entrepreneur}

Entrepreneurial activities are believed that it can be a tool to boost economic growth and to address economic problems such as unemployment. Analyzing data from the Statistics Central Bureau of the World Bank and Indonesia shows the increase number and the growth of unemployment which come from graduate, in this case, entrepreneurship can be a solution. Therefore, we must find ways to create new entrepreneurs, right after or even before they graduate. In other words, we have to produce more self-employed graduates and entrepreneurial education that may have a role in promoting entrepreneurial intentions among students [4].

Entrepreneurship education is the process of providing individuals with the ability to recognize the commercial opportunities and insights, self-esteem, knowledge and skills to act upon them. These include instructions on opportunity recognition, commercializing concepts, gathering resources at risk, and starting a business. Entrepreneurship education should be defined in a structurally formalized intervention designed by higher education institutions. Otherwise, it becomes an informal learning that can be pursued without formal education or training institutions. Many authors agree on the adoption of a broad concept of entrepreneurship education, derived from a combination of organized teaching and institutional support.

Instead of limiting only as a single entrepreneurship course, entrepreneurship education consists of various courses to develop comprehensive entrepreneurial competencies. It is also not limited to major or entrepreneurship concentrations [5].

Given the importance of entrepreneurship education in every generation, there are several reasons why entrepreneurship education should be applied in the education world that most young people do not grow up in entrepreneurial culture first. Inspiration and business practice are not much taught in school. The two high rates of unemployment in Indonesia are not considered graduation. The three jobs are very limited, not proportional to the number of job seekers. The fourth growth of enterpreneur in addition can accommodate the workforce so it can create welfare of society widely.

Fifth, Indonesia is very rich in natural resources, but the existing natural resources are not maximum in management system due to the lack of human resources capabilities. Enterpreneurship can be learned and it can create sufficient quantity of enterpreneur in Indonesia. Then in the need of quantum leap, there are three ideas. First, at the level of basic education, there should be a curriculum that teaches about entrepreneurship. Second, entrepreneurs must be created and developed and at the college level. Third, there is a national movement of entrepreneurship training undertaken by the government and society, so that the movement can reach out to the wider community outside the school [6].

Scientists believe that entrepreneurial career choices chosen by individuals are influenced by the various "encouragement" and "pulling" factors that determine and shape their career choices. This is the role of entrepreneurship education that can help students to consider starting a business as one alternative career, and developing a positive attitude towards entrepreneurship. Entrepreneurship education given in business schools will result in more graduates becoming entrepreneurs. Other scholars also believe the same things. It is generally recognized in the literature that entrepreneurial knowledge and skills can be taught and developed in an appropriate environment.

There is a close relationship between learning and entrepreneurial achievement (Rae and Carswell; Kuratko and Hodgetts; Van Vuuren; Gibb; in Sarri, Bakourus \& Petridou, 2010). In terms of intentions, Mushtaq et.al (2011) reported that all variables, including their Indonesian 
education studies significantly correlated with intentions to create new ventures, as well as Turker and Selcuk research findings (2009). Furthermore, the study also showed a significant difference between students participating in entrepreneurship education in terms of intent.

Students with business majors (a) consider themselves more entrepreneurial, (b) more likely to start their own business, (c) feel that entrepreneurial skills are part of their curriculum, (d) feel there is more university stimulation, and (e) are significantly more likely to say they are interested in taking entrepreneurship courses. Success in the future of our collective global will rely on current students by using the age of 21 years of skills to develop innovative solutions to the key issues of society Entrepreneurs, in turn, are individuals who turn this innovation into economic goods that use financial and business acumen. In the long term, the economic health of each region depends on several degrees on what it does to help these people succeed. Success in our global, collective future will depend on the students today by using $21^{\text {st }}$ century skills to develop innovation.

The solutions for community Entrepreneurs key issue, in turn, are individuals who transform this innovation into economic goods that use financial and business intelligence. In the long run, the economic health of each region depends on a certain level on what it does to help these people succeed. Entrepreneurship encourages economic change and innovation while at the same time expanding opportunities and releasing citizen initiatives. Entrepreneurs are essential to building a prosperous society that gives opportunity to all powerful citizens.

The 21st Century not only knows how to use technology, but also how to use technology to turn innovation into services, goods, or efficiencies that contribute to local and regional economies, and perhaps most importantly is the economy itself home. In developing countries around the world, today's entrepreneurial interests are higher than ever in the middle of the growing population of youth and the desire to move up the chain value. Educational entrepreneurship is delivered on the basis of 21 st century skills, both in educational institutions and as a key element of lifelong learning, needed to encourage innovation and therefore the economic of a region is health.

Entrepreneurship education is essential for successful innovation. This section discusses the proposed methodology, the intended audience, and the importance of introducing core knowledge to activate the innovation process as well as the need to change the mindset that can hamper the process. They added that, methodologically, the program relies on design thinking, case analysis and simulation, and active learning to develop the competencies needed for the difficult task of starting a new business. Conceptually speaking, competencies are developed to understand the external business environment, assessing the capabilities and resources of employers and their teams, and building and analyzing business models for new businesses, while using companies that do the same or opposite as reference models [7].

\section{FINDING RESEARCH AND DISCUSSION}

Based on the merging of the theory and experience in the field, we can draw the conclusion that the entrepreneurship education is very important to be applied from early childhood. The students can develop their ability to interact with others, foster courage and confidence if entrepreneurial education is given at the age of 4 to 5 or at the level of kindergarten. It will be more developed if the sustainable model of enterpreneur learning is advanced at elementary school level. They will find experiences of how they interact with outsiders that they have never met before, must take decisive steps in figuring out how to get their business to grow, and also be able to overcome the comments of rejection and feedback from castors. The role of the teachers, they must be more active in growing the students' great souls in the success by giving motivation and strong support needed by the students. Besides, they need to develop their positive thinking and optimistic to raise the spirit of the students. Giving pictures to the students added to the books that we learned in the classroom, there are lessons that must be learned outside the classroom. The development of students' knowledge in elementary school age is very fast and significant so that they will be able to invite creative thinking and much more challenging. What they need is recognition of their ability and time to work.

Implementation of this entrepreneur learning model must have been applied in some schools, and we conducted this research in elementary school.

\section{CONCLUSIONS}

Looking at the importance of entrepreneurship education in each generation, there are several reasons why entrepreneurship education should be applied in the education world, with motivations to foster entrepreneurial spirit within each generation, high unemployment rate, lack of employment equal to the number of job enthusiasts, and can also create welfare of the community at large and in order to manage the natural resources maximally. The steps are establishing the curriculum of entrepreneurship learning program in every level of education from the age of early childhood to college school, to create a generation that can meet the needs of its foundation, and create professional employment.

Second, from the results of the invesment we found by applying the enterpreneur learning model at the primary school level, so much learning is gained by students like encourage confidence, communication, socialization, independence and also responsibility. This research is focused on the level of students' spiritual intelligence. The application of the entrepreneur's learning model in improving the students' spiritual intelligence can be seen, coordinated in controlling the time, the creation of a character of gratitude for what they have or they find, 
honesty in communicating and most importantly the students know how the parents work in seeking rizki and collecting money for school fees, that is not easy in growing a sense of solidarity of a child against the difficulties and inconveniences of parents in collecting rizki, because current generation get almost everything easily and instantly.

Third, there is cooperation and support between parents and teachers. The researcher sees the students are comfortable and free in learning, they experience and practice directly in learning. This is the beginning of the formation of a tough generation that can uplift the Nation's economy. According to the hadith, "The strong Mukmin (believers) are better and loved by Allah than the weak ones." If the generation can think strongly positive, haviing long-term futuristic view, and innovative, then this nation will be strong and prosperousss.

\section{ACKNOWLEDGMENT}

I put on my greatest thanks to Universitas Muhammadiyah Sidoarjo for pubishing this article.

\section{REFERENCES}

[1] M. Musfiqon, "panduan lengkap Metodologi Penelitihan Pndidika", Surabaya : Prestasi Pustaka,

[2] T. Trianto." Model Pembelajaran Inovatif Berorentasi Konstruktivistik”, Jakarta : Pustaka, 2007

[3] Sarliaji Cayaray "Model layanan Perpustakaan Sekolah Luar Biasa" (Unifersitas Pendidikan Indonesia) Repository.Upi.du

[4] Hindawi, Enterpreneurship Education In Health car Education, 2014

[5] Hindawi, Enterpreneurship Education In Health car Education, 2014

[6] Pasca. UGM.ac.id > News

[7] Mery Citra Sondari "Is Enterpreneurship ducation Reallyneeded?: Examining the Antecadene of Enterpreneurrial Career Intertion.( $201444-53$ ) 